\title{
The Academic Knowledge Management Model of Small Schools in Thailand
}

\author{
Chamnan Tumtuma ${ }^{1}$, Chalard Chantarasombat ${ }^{1} \&$ Theerawat Yeamsang ${ }^{2}$ \\ ${ }^{1}$ Faculty of Education, Mahasarakham University, Thailand \\ ${ }^{2}$ Faculty of Education, Mahasarakham Rajabhat University, Thailand \\ Correspondence: Chamnan Tumtuma, Faculty of Education, Mahasarakham University, Thailand. Tel: \\ 66-81-974-5083. E-mail: chamnan09@hotmail.co.th
}

Received: April 26, 2015 Accepted: August 21, 2015 Online Published: October 28, 2015

doi:10.5539/ies.v8n11p266 URL: http://dx.doi.org/10.5539/ies.v8n11p266

\begin{abstract}
The Academic Knowledge Management Model of Small Schools in Thailand was created by research and development. The quantitative and qualitative data were collected via the following steps: a participatory workshop meeting, the formation of a team according to knowledge base, field study, brainstorming, group discussion, activities carried out according to knowledge, summarizing and revising the operation, organizing an exhibition to show the work results, and the creation of a website. The results showed that the subjects had knowledge of how to manage knowledge, became more academically capable, and were satisfied with knowledge management at the highest level.
\end{abstract}

Keywords: knowledge management, academic knowledge management, small-sized schools

\section{Introduction}

\subsection{Introduce the Problem}

A key factor for educational development is the development of learners in line with educational standards and social needs. The National Educational Plan (2009-2016) stipulated that it is important to have life which was perfect physically, mentally and intellectually. Individuals have to have knowledge and virtues, morals and culture in order to live happily with others. Thailand has a policy of life-long learning. Three key goals are to develop the quality and standard of Thai education, increase educational opportunity, and promotion of participation of all parties concerned. There are four major issues of education which are to be urgently reformed: 1) development of human quality and education; 2) development of a new generation of teachers and educational personnel; 3) development of education quality and learning sources, and 4) development of new administration, with distribution of administrative power to increase educational opportunity and effectively manage educational resources (Samutprakan Primary Educational Service Area Office 2, 2011).

\subsection{Explore Importance of the Problem}

There are increasing problems related to the quality of learning and teaching, particularly concerning the efficiency and achievement of learners. There are numerous factors which can have an immense impact on the desired goals of small schools. The problems become more particularly serious for the primary small-sized schools. One of the problems is the decreasing number of students. In addition, these small schools face other problems: insufficient numbers of teachers, inadequate learning media, lack of sufficient educational resources, etc. All these factors are responsible for low quality education and underachievement. As a result, it is deemed extremely important to determine the strategies to solve the various problems described above so that the small schools have more potential and become more efficient.

\subsection{Describe Relevant Scholarship}

Knowledge management is a new model emphasizing a systematic working process by making use of knowledge along with learning practical skills and attitudes by analyzing, and organizing knowledge to select, exchange and disseminate information which is correct, accurate, appropriate and favorable. The goal of knowledge management is to enhance a competitive ability of an organization (Keerati, 2006; Propon, 2007; Burachai, 2009; Wijan, 2009). Knowledge management is a coordinated process requiring participation from several parties in 
order to know and determine the problems, their solutions and the goals. Evaluation and practice are to be conducted and constant improvements are imperative. According to Chantarasombat (2009), any method which aimed to develop an individual or a group through an exchange of knowledge and experience was called knowledge management. For this management to be successful, hard-to-learn technology should be avoided. Instead, focus should be on simplicity. More difficult methods should be applied after as per necessity (Wijan, 2006).

\subsection{Hypothesis and Its Correspondence to Research Design}

Knowledge management in small schools requires the cooperation of all parties concerned: researchers, managers of knowledge, resources and procedures. Cooperation is required to achieve the set goals. Evaluation is necessary, and constant improvements are to be made. Information, knowledge and techniques are to be exchanged. Development is indispensible to a curriculum, a learning process, learning sources and humans. Chantarasombat (2007) conducted research on a model of knowledge management of a community and found that knowledge and development should be consistent with local circumstances. A primary aim of knowledge management of an organization or institute is to bring about participation of members, to promote an exchange of knowledge, to be creative, to improve relations of participating members in making a decision and assuming accountability. Research by Namnaphon (2008) examined the development of a knowledge-management model in small schools. The study found that with the model in place, the school administrators and teachers had more leadership, the school had a positive working atmosphere, and results got higher. The teachers were more responsible for their duties and learners' achievement was higher.

It is obvious that knowledge management in small schools is beneficial to educational quality. Furthermore, the management of knowledge can be a guideline to increase the efficiency and quality of small schools. As an administrator of a small school, the researcher wishes to maximize the knowledge management method with cooperation from all parties concerned. The results gained can be utilized to develop the quality of the school and used as a prototype for school development.

\section{The purposes of the study}

- To develop an academic management model for small schools in Thailand.

- To study the results of the application of the said academic management model.

- To study the level of satisfaction towards the implementation of an academic management model of and for small schools in Thailand.

\section{Methodology}

The research employed a research and development approach (Dalkir, 2005; Meyer \& Zack, 1996) as well as participatory action research (Chantarasombat, 2008; Kamon, 1994; Pantip, 1997; Elliott, 1981; Kemmis \& McTaggart, 1988; McKernan, 1996). The process of establishing an academic management by the small schools was undertaken in three steps:

1) The construction of a conceptual framework

2) Meeting to make an operation plan consisting of the following:

- Participatory meeting

- Formation of a team according to knowledge standard

- Field study

- Brainstorming

- Discussion

- Undertaking of activities

- Holding a seminar

- Clarification

- Exhibition

- Creation of a website

3) Exploration of satisfaction levels 


\section{Conclusions}

The research results can be concluded as follows.

1) Results of the model development

1.1) The academic management model was based on the knowledge management theory of Chantarasombat (2007), Wijan (2003), Kaewvieng (2008), Prophon (2007), Wiig (1993), Nonaka and Takeuchi (1995), McElroy (1999), Bokowitz and Williams (2000), and Jennex (2005).

Five knowledge-management processes are illustrated in Figure 1.

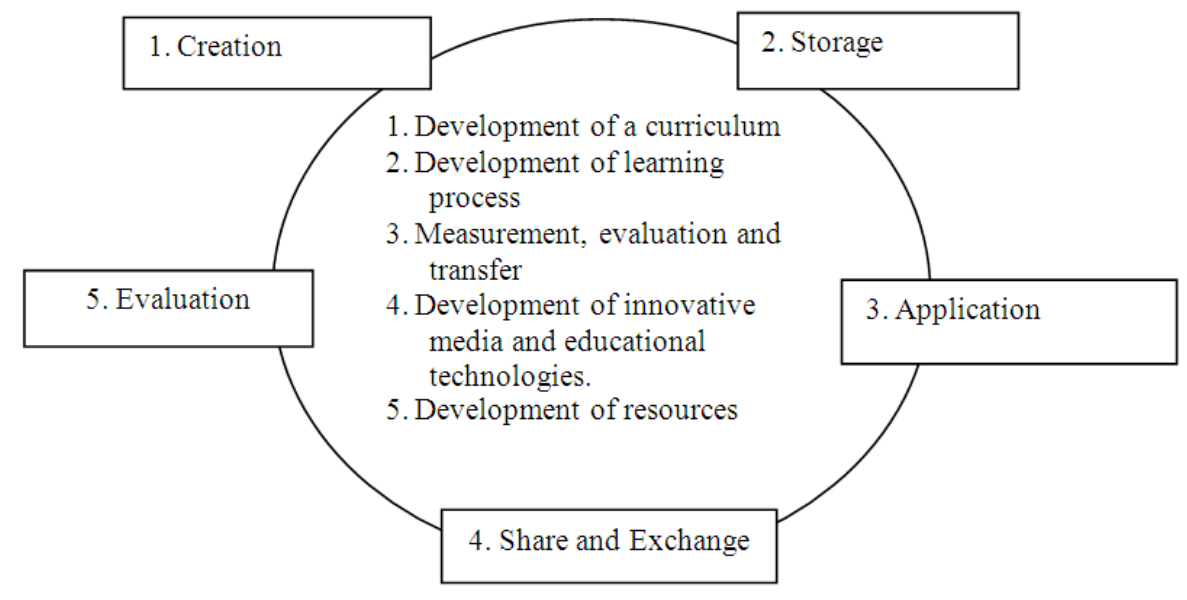

Figure 1. Conceptual framework in constructing a model

1.2) An operation plan was founded on five aspects of academic affairs and participatory action research, as demonstrated in Figure 2.

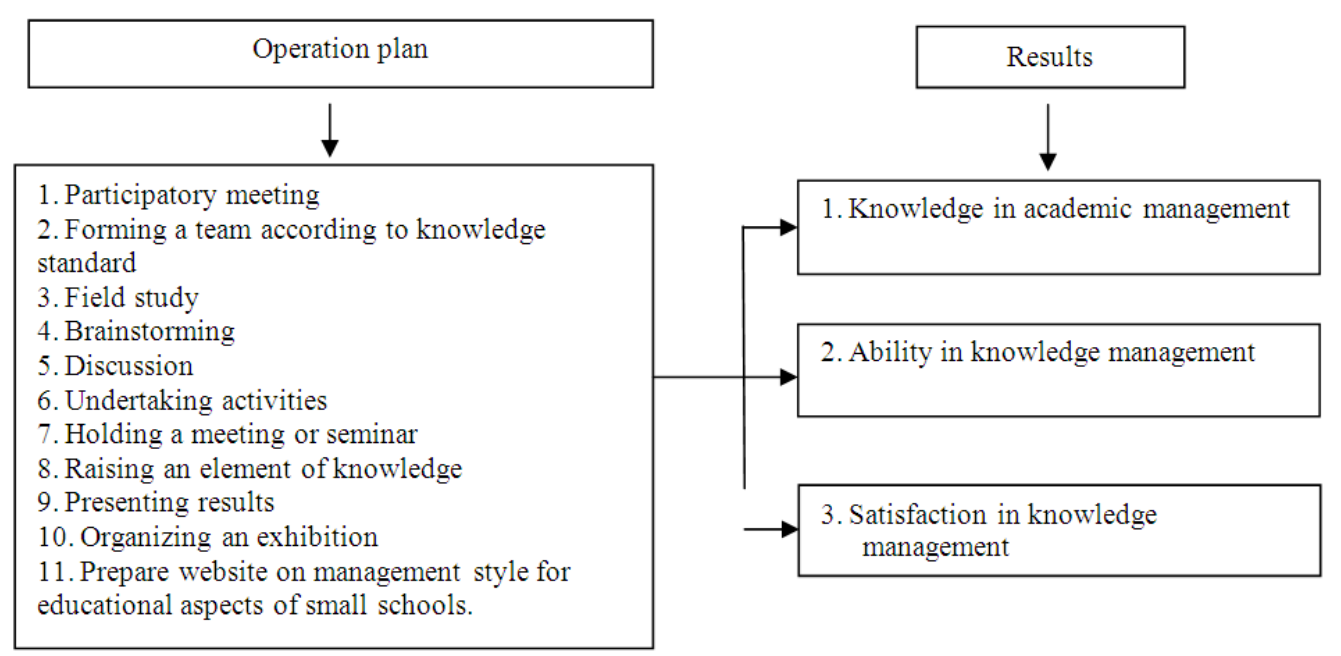

Figure 2. An operation plan for knowledge management

2) The results showed that following the implementation according to the operation plan, three sets of knowledge-elements were acquired: knowledge of raising pigs, knowledge of weaving reed mats, and knowledge of basketry. Based on the application of knowledge in the areas in question, it was found that:

2.1) An application of an academic management model by the small schools in the study showed that the model 
had an efficiency of a process/result equivalent to $85.44 / 80.25$.

2.2) The use of the knowledge management model according to occupational knowledge showed that the model had an efficiency of a process /result equivalent to 84.78/80.26.

2.3) The use of the knowledge management model according to a principle of increasing an income showed that the reed mat weaving had an efficiency of a process/result equivalent to 86.45/80.74.

2.4) Considering the use of the model in terms of increasing raw materials, the model had an efficiency of a process /result equivalent to $85.11 / 80.74$.

3) The average satisfaction of the research team towards an implementation of the knowledge management model of the small schools was found to be at the highest level.

\section{Discussion}

I) In conducting this research, five learning-steps were entailed: creating knowledge, maintaining or keeping knowledge, applying knowledge, sharing and exchanging knowledge, and evaluating knowledge. A framework was developed in five aspects: development of a school curriculum; development of learning processes; measuring, evaluating and transferring learning results; development of educational media, innovation and technology; development of learning sources. There were eleven steps of operation: participatory workshop meeting, formation of a team according to knowledge base, field study, brainstorming, group discussion, performance of activities, meeting to summarize and revise an implementation, clarification of knowledge elements, exhibition to show results, and the creation of a website. Development came from the participation of the many parties concerned: school administrators, teachers, school committees, students, and community leaders. Chatarasombat (2007) said that knowledge management was a process involving many aspects. To wit, knowledge was established, a common question was made, a common learning was shared, knowledge was applied, results were evaluated, constant improvements were necessary. Prawet (2002) explained that knowledge management was research to build knowledge. To achieve that, it is important to have a common goal, common research, and common learning. According to Insee (2007), there is a wide variety of knowledge management. Attention should not be given to difficult technology. Instead, attention should be paid first to simplicity before gradually proceeding to more difficult or complex steps. Nanoka and Takeuchi (1995) said knowledge was a creation of knowledge and innovation; it was rooted in creativity and holistic practice. Everything was naturally related. Knowledge to be gained was to undergo an interaction process between tacit knowledge and explicit knowledge known as 'SECI'. Henry and Hedped (2003) argued that knowledge management was both tacit and explicit; the system was associated with classification, verification and maintenance of knowledge; a primary aim was for knowledge to be used and improved upon.

II) As regards the use of the knowledge management model in the small-sized schools in Thailand, it was found that the research team had a better knowledge in academic affairs, become more capable of managing academic affairs and more satisfied with management. Chatarasombat (2007) viewed that a concept of knowledge management led to seven aspects: indication of knowledge, creation of knowledge, classification, keeping knowledge, application, sharing and exchanging, and evaluation. The concept proposed was in accordance with the idea of Boondee et al. (2006) who proposed that there were concepts for knowledge management processes: search of knowledge, creation of knowledge, keeping knowledge, processing and selecting knowledge, accessing knowledge, sharing and exchanging knowledge, and learning. Nanoka and Takeuchi (1995) advanced a concept of knowledge management as follows: vision of knowledge, forming a team to manage knowledge, building an atmosphere, managing knowledge and activities, creating a new model for an organization, changes for an organization, and building a network with an outside world. Bokowitze and Williams (2000) explained a process and theory of knowledge management in five integrated steps: creation of knowledge, division of knowledge, dissemination, application and evaluation of knowledge. McElroy (1999) described a circle of knowledge management as consisting of: a process related to output, keeping it, integration of knowledge, application and evaluation of knowledge.

III) With respect to the level of satisfaction towards the research results, it was found that the researchers were satisfied with the knowledge management model at the highest level. The finding was similar to that found by Chatarasombat (2007) who conducted a research on a development of a model of knowledge management of a community organization and found that the community was satisfied with the model at the high level. The result was also consistent with that found by Namnaphon (2008) who conducted research on a knowledge management model and found that the satisfaction of the teachers and the school committee was at the highest level. The reason for this was there were coordination and cooperation from the administrators, teachers, students, communities and education committees. Homsin (2013) did research on public-mindedness of secondary 
students and found satisfaction on all sides concerned at the highest level.

\section{Acknowledgements}

The researchers would like to express their thanks and gratitude to the Faculty of Education, Mahasarakham University, Thailand for the financial support of this research paper.

\section{References}

Bokowitz, W., \& Williams, R. (2000). The Knowledge Management Field Book. London: Practice Hall.

Boonyakit. (2005). Knowledge Management from Theory into Practice. Bangkok: Jirawat.

Chantarasombat, C. (2007). Development of Knowledge Management Model for Community Organization (Doctoral of education thesis, Mahasarakam University).

Chantarasombat, C. (2008). Participatory Action Research for Community Development (2nd ed.). KhonKaen: Klangnanawittaya.

Chanthtarasombat, C. (2009). Development a Knowledge Management Model for Self-Reliant Communities. Medwell Journals, 4(4), 392-396.

Dalkir, K. (2005). Knowledge Management in Theory and Practice. USA: Jordan Hill.

Elliott, J. (1981). Action Research. Cambridge, Institute of Education: London.

Henrie, \& Hedgepeth. (2003). Size Is Important In Knowledge Management. Journal of Knowledge Management, Practice. Retrieved from http://www.tlainc.com/articl53.htm

Homsin, N. (2013). A Model of Knowledge Management for Public Mind Development of Secondary School Students (Doctoral of Education Thesis, Mahasarakam University).

Intree, C. (2007). The development of knowledge management (Doctoral of Education Thesis, Faculty of Nursing Ratchathani University, Mahasarakam University).

Jennex, M. E. (2005). What is Knowledge Management? International Journal of Knowledge Management, l(4).

Kemmis, S., \& McTaggart, R. (1988). The Action Research Planner. Victoria: Deakin University Press.

McElroy, M. (1999). The Knowledge Life Cycle Englewood Cliffs. New Jersey: Prentice-Hall.

McKernan K. (1996). Curriculum Action. Research (2nd ed.). London: Kogan Page.

Meyer, M., \& Zack, M. (1996). The Design and Implementation of Information Products. Sloan Management Review, 37(3), 43-59.

Namnapon, K. (2008). The development of a knowledge management in a small study (Doctoral of education thesis, KhonKaen University).

Nonaka, I., \& Takeuchi, H. (1995). The Knowledge-Creating Company: How Japanese Companies Create the Dynamics of Innovation. New York: Oxford University Press.

Panich, W. (2005). Knowledge Management: Practitioner Issue. Bangkok: The Institute Promoting the Knowledge Management for Society (IKS).

Pasukyead. (2007). Knowledge Management KM by the LO. Bangkok: Yaimai.

Phahay, S. (1971). Multi-grade Teaching in Small Schools. Retrieved September 30, 2014, from http://www.addkutec. 3com/wp-content/uploads/2014/02

Prawet, W. (2002). Knowledge Management. Reform Journal, 5(5), 74-76.

Ramasoota, P. (1997). Participatory Action Research (1st ed.). Bangkok: P.A. Living.

Samutprakan Primary Educational Service Area Office 2. (2011). Develop effective management plans for small schools.

Sirimahasakorn, B., \& Kwangtong, P. (2009). All the Way to the Intelligent Enterprise Knowledge Management. Bangkok: Sangdao.

Sudprasert. (1994). The Research was Conducted with the Participation of the Workers. Bangkok: Office of Human Resources Development.

Wiig, K. (1993). Knowledge Management Foundations. Arlington, TX: Schema Press. 
Wijan, P. (2009). Unregulated to Regulated. Bangkok: The Institute Promoting the Knowledge Management for Society (IKS).

\section{Copyrights}

Copyright for this article is retained by the author(s), with first publication rights granted to the journal.

This is an open-access article distributed under the terms and conditions of the Creative Commons Attribution license (http://creativecommons.org/licenses/by/3.0/). 